\title{
Development of power operated medicinal nut sheller
}

\author{
R.A. BANGALE, P.A. TURBATMATH, R.V. SANGLIKAR, V.D. DESHMUKH, J.S. DESHPANDE \\ AND M.R. BEDIS
}

Received : 09.07.2015; Revised : 19.08.2015; Accepted : 15.09.2015

See end of the Paper for authors' affiliation

Correspondence to :

\section{P.A. TURBATMATH}

Dr. Annasaheb Shinde College of Agricultural Engineering, Mahatma Phule Krishi Vidyapeeth, Rahuri, AHMEDNAGAR (M.S.) INDIA Email : adcae.mpkv@gmail.com
-ABSTRACT : Medicinal nuts like hirada and ritha have many medicinal properties and used for many pharmaceutical operations. Presently shelling of hirada (Terminalia chebula) and ritha (Sapindus mukorossi) nuts is done manually, which is labour intensive, slow and tedious operation. Therefore, a power operated medicinal nut sheller was developed on the basis of shear principle. The capacity of the machine has been observed to be $114 \mathrm{~kg}-\mathrm{h}^{-1}$ and $170 \mathrm{~kg}-\mathrm{h}^{-1}$ for hirada and ritha nuts, respectively. Shelling efficiency of nuts was 83 per cent and 80.66 per cent for hirada and ritha, respectively. Per cent broken seeds were observed as 28.9 per cent and 7.9 per cent for hirada and ritha, respectively.

- KEY WORDS : Hirada, Terminalia chebula, Ritha, Sapindus mukorossi, Nut sheller, Shelling efficiency, Shear

- HOW TO CITE THIS PAPER : Bangale, R.A., Turbatmath, P.A., Sanglikar, R.V., Deshmukh, V.D., Deshpande, J.S. and Bedis, M.R. (2015). Development of power operated medicinal nut sheller. Internat. J. Agric. Engg., 8(2) : 206-209. 